\title{
The biological role of autophagy in regulating and controlling the proliferation of liver cancer cells induced by bufalin
}

\author{
XIA SHENG ${ }^{1}$, PENGFEI ZHU ${ }^{2}$, JIANMIN QIN $^{2}$ and QI $\mathrm{LI}^{3}$ \\ Departments of ${ }^{1}$ Pathology and ${ }^{2}$ General Surgery, The Third Hospital, Affiliated to \\ The Second Military Medical University, Shanghai 201805; ${ }^{3}$ Department of Medical Oncology, \\ Shuguang Hospital, Shanghai University of Traditional Chinese Medicine, Shanghai 201203, P.R. China
}

Received August 11, 2017; Accepted March 29, 2018

DOI: $10.3892 /$ or.2018.6365

\begin{abstract}
Autophagy is an important mechanism which regulates the processes of cell growth and death. The biological role of autophagy in regulating and controlling the proliferation of liver cancer cells by bufalin remains unknown. In the present study we investigated the effect of bufalin on autophagy of liver cancer cells. The growth inhibition and autophagy of liver cancer cells were detected using acridine orange fluorescence staining, flow cytometry and transmission electron microscopy. Combined with autophagy inhibitors (3-MA and CQ), CCK8 staining and western blot analysis were used to detect the effect of bufalin on the proliferation and autophagy-related protein expression in HCC-LM3 cells at the indicated time-points. Results indicated that combined with autophagy inhibitors 3-MA and CQ, the inhibitive effect of bufalin on the proliferation of HCC-LM3 cells was significantly enhanced. When combined with autophagy inhibitors 3-MA or CQ, bufalin significantly reduced the autophagosome and acidic vesicles in HCC-LM3 cells. When combined with autophagy inhibitors 3-MA and/or CQ for $12 \mathrm{~h}$, bufalin significantly inhibited the expression of LC3-I and Beclin-1 in HCC-LM3 cells, and upregulated the expression of LC3-II and P62 in HCC-LM3 cells. When combined with autophagy inhibitors 3-MA and/or CQ for $24 \mathrm{~h}$, bufalin significantly inhibited the LC3-II expression in HCC-LM3 cells, and upregulated the LC3-I, P62 and Beclin-1 expression in HCC-LM3 cells. When combined with autophagy inhibitors 3-MA and/or CQ for $48 \mathrm{~h}$,
\end{abstract}

Correspondence to: Professor Jianmin Qin, Department of General Surgery, The Third Hospital, Affiliated to The Second Military Medical University, 700 North Road, Moyu, Jiangding, Shanghai 201805, P.R. China

E-mail: jianminqin@yahoo.com

Abbreviations: HCC, hepatocellular carcinoma; DMEM, Dulbecco's modified Eagle's medium; FBS, fetal bovine serum; 5-FU, 5-fluorouracil; 3-MA, 3-methyladenine; CQ, chloroquine

Key words: bufalin, hepatocellular carcinoma, autophagy, proliferation bufalin significantly inhibited the expression of LC3-II and Beclin-1 in HCC-LM3 cells, and upregulated the expression of LC3-I and P62 in HCC-LM3 cells. These findings indicated that bufalin induced cell autophagy and inhibited proliferation of liver cancer cells by influencing the expression of autophagy related proteins including LC3-I, LC3-II, P62 and Beclin-1 in liver cancer cells. The autophagic state of liver cancer cells affected the inhibitory effect of bufalin on the proliferation of liver cancer cells.

\section{Introduction}

Autophagy is an important mechanism for regulating the process of cell growth and death and is a highly conserved process which can maintain the metabolic balance and preserve stable environmental energy to maintain cell metabolic needs (1). Autophagy can inhibit the chromosomal instability by inhibiting protein aggregation, as well as organelle and chromosome damage. Tumor cells with apoptotic dysfunction can maintain long-term survival by autophagy which reduces cell necrosis, inflammation and genetic damage. Autophagic abnormality is closely related to the occurrence and development of hepatocellular carcinoma (HCC). Ding et al (2) found that the lower autophagic activity of liver cells at a precancerous stage was closely related to the malignant behavior and prognosis of HCC, and there was loss of the expression of the autophagy-related gene Beclin-1 during the carcinogenesis of HCC induced by chemical carcinogens. Autophagy can inhibit the occurrence of HCC, however autophagy occurred in liver cancer cells when they were under hypoxia, drug or toxic chemical damage. Cytoplasmic vesicles made from double membrane coated material to be degraded form the autophagosomes, and then the autophagosomes and lysosomes combine to form autolysosome. The degraded substances in vesicles are digested, hydrolyzed and released into the cytoplasm to be used again and aid liver cancer cells to tolerate hypoxic conditions and resist chemotherapy. Therefore, autophagy plays a role of 'double-edged sword' in the occurrence and development of tumors. Under different conditions, the promoting or inhibiting effect of autophagy on the proliferation of tumor cells mainly depends on the cell state and survival environment as well as the stimulating factors (3-5). Bufalin, which is derived from the traditional Chinese medicine named 'Chan Su', has strong 
toxicity, can destroy the rough-surfaced endoplasmic reticulum of mitochondria in tumor cells by inhibiting the synthesis of DNA and RNA in tumor cells, induce differentiation and apoptosis of tumor cells, and inhibit tumor angiogenesis, and then inhibit the proliferation of tumor cells (6-8). Our previous study indicated that bufalin could significantly inhibit proliferation, invasion and metastasis of liver cancer cells by blocking cell cycle at the S and G2 phase in BEL-7402 hepatoma cells, and the inhibitive efficacy was time- and dose-dependent (9). Bufalin can inhibit the downstream target molecules of MMP-2 and MMP-9 in liver cancer cells by influencing the expression of Gli1 protein in the Hh-signaling pathway. Bufalin can upregulate the expression of E-cadherin and downregulate the expression of $\beta$-catenin and VEGF in liver cancer cells by influencing the Gli3 protein expression of the Hh-signaling pathway. Bufalin combined with the inhibitors of Hh-signaling pathway can significantly reduce the malignant biological behavior of liver cancer cells via the Hh-signaling pathway (10). Our previous studies revealed that bufalin inhibited the EMT of HCC cells by increasing the inter-membrane E-cadherin/ $\beta$-catenin complex. This is the key mechanism of bufalin against cell proliferation, invasion and metastasis of HCC cells $(11,12)$. However, the exact mechanism of inhibiting HCC growth and inducing apoptosis of liver cancer cells has not yet been fully elucidated. In the present study we examined cultured human liver cancer cells and observed the effects of bufalin on liver cancer cell proliferation by influencing the cell autophagic state. Therefore, the present study provided new theoretical basis for developing new related molecular targeted drugs to treat HCC by studying the effects of bufalin on liver cancer cell autophagy.

\section{Materials and methods}

Reagents. Bufalin, purchased from Sigma Chemical Co. (St. Louis, MO, USA), was dissolved in anhydrous alcohol at a concentration of $10^{-1} \mathrm{~mol} / \mathrm{l}$ and stored at $4^{\circ} \mathrm{C}$. High glucose Dulbecco's modified Eagle's medium (DMEM) and fetal bovine serum (FBS) were purchased from Gibco Laboratories (Gaithersburg, MD, USA). In addition, 5-fluorouracil (5-FU) was purchased from Shanghai Xudong Haipu Pharmaceutical Co., Ltd. (Shanghai, China) and 3-methyladenine autophagy inhibitor (3-MA) was obtained from Gibco Laboratories and was diluted to $5 \mathrm{mmol} / \mathrm{l}$ DMEM containing 10\% FBS. Chloroquine autophagy inhibitor (CQ; Sigma Corporation of America, Ronkonkoma, NY, USA), was diluted to $5 \mu \mathrm{g} / \mathrm{ml}$ DMEM containing 10\% FBS. Acridine orange and Cell Counting Kit-8 (CCK-8) were obtained from Sigma Corporation of America.

Cell lines. HCC-LM3 cells were obtained from the Liver Cancer Institute of Zhongshan Hospital Affiliated to Fudan University. The cells were cultured in high-glucose DMEM supplemented with $10 \% \mathrm{FBS}, 100 \mathrm{U} / \mathrm{ml}$ of penicillin and $100 \mu \mathrm{g} / \mathrm{ml}$ of streptomycin in a humidified atmosphere with $5 \%$ $\mathrm{CO}_{2}$ in air at $37^{\circ} \mathrm{C}$. Subsequently, the cells in the logarithmic growth phase were collected for the following experiments.

Grouping. HCC-LM3 cells were cultured in vitro and were divided into the following groups: Control, 5-FU, bufalin, bufalin +3-MA, bufalin + CQ and bufalin +3-MA + CQ.
Cell proliferation assay. The HCC-LM3 cells were cultured in high-glucose DMEM supplemented with $10 \%$ FBS in a humidified atmosphere with $5 \% \mathrm{CO}_{2}$ at $37^{\circ} \mathrm{C}$. Then, the cells in the logarithmic growth phase in each group, were pretreated with autophagy inhibitors 3-MA (the effective dose concentration of $5 \mathrm{mmol} / \mathrm{l}$ ) and/or CQ (the effective dose concentration of $5 \mu \mathrm{g} / \mathrm{ml}$ ) for $12 \mathrm{~h}$ in 96 -well plates. Subsequently, $5 \mathrm{ml}$ DMEM plus $10 \%$ FBS was injected into culture plates in the control group, $5 \mathrm{ml} \mathrm{5-FU}\left(186 \mu \mathrm{g} / \mathrm{ml}, \mathrm{IC}_{50}\right.$ of $5-\mathrm{FU}$ for HCC-LM3 cells at $24 \mathrm{~h}$ ) was injected into culture plates in the 5 -FU group, $5 \mathrm{ml}$ bufalin $\left(0.12 \mu \mathrm{g} / \mathrm{ml}, \mathrm{IC}_{50}\right.$ of bufalin for HCC-LM3 cells at $24 \mathrm{~h}$ ) was injected into culture plates in the bufalin, the bufalin +3-MA, the bufalin + CQ and the bufalin +3-MA + CQ groups. The cells in each group were cultured in a humidified atmosphere with $5 \% \mathrm{CO}_{2}$ at $37^{\circ} \mathrm{C}$ for $24 \mathrm{~h}$. The culture medium in each group was discarded, and then $100 \mu \mathrm{l} \mathrm{CCK-8}$ was injected into the culture plates of each group in the dark. Following incubation in a humidified atmosphere with $5 \% \mathrm{CO}_{2}$ at $37^{\circ} \mathrm{C}$ for $1.5 \mathrm{~h}$, the absorbance at $450 \mathrm{~nm}$ was detected by an automatic microplate spectrophotometer (SpectraMax 190; Molecular Devices, Sunnyvale, CA, USA). Each experiment was performed in triplicate. The cell inhibition ratio was calculated using the following formula: Growth inhibition ratio $(\%)=[1$ - (average absorbance of the treated group-average absorbance of the blank group)/(average absorbance of the control group-average absorbance of the blank group)] x $100 \%$.

Analysis of the autophagosome and autophagolysosome formation of liver cancer cells. The HCC-LM3 cells were cultured in high-glucose DMEM supplemented with $10 \%$ FBS in a humidified atmosphere with $5 \% \mathrm{CO}_{2}$ at $37^{\circ} \mathrm{C}$. Subsequently, the cells in the logarithmic growth phase were plated at a density of $2.5 \times 10^{6}$ cells $/ \mathrm{ml}$ and then at $100 \mu \mathrm{l} / \mathrm{well}$ in 6-well plates. Twelve hours later, the cells in each group were pretreated with autophagy inhibitors 3-MA (5 mmol/l) and/or CQ $(5 \mu \mathrm{g} / \mathrm{ml})$ for $12 \mathrm{~h}$. In addition, $5 \mathrm{ml}$ DMEM plus $10 \%$ FBS was injected into culture plates in the control group, $5 \mathrm{ml} \mathrm{5-FU}(186 \mu \mathrm{g} / \mathrm{ml})$ was injected into culture plates in the 5-FU group, $5 \mathrm{ml}$ bufalin $(0.12 \mu \mathrm{g} / \mathrm{ml})$ was injected into culture plates in the bufalin, the bufalin +3-MA, the bufalin + CQ and the bufalin +3-MA+CQ groups. The cells in each group were cultured in a humidified atmosphere with $5 \% \mathrm{CO}_{2}$ at $37^{\circ} \mathrm{C}$ for $24 \mathrm{~h}$. The cells in each group were collected by centrifugation $\left(2,504 \mathrm{x} \mathrm{g}\right.$ at $4^{\circ} \mathrm{C}$ for $\left.10 \mathrm{~min}\right)$, fixed with $2.5 \%$ glutaraldehyde solution for $12 \mathrm{~h}$, and then fixed with $1 \%$ Osmium tetroxide solution for $2 \mathrm{~h}$. Finally, the gradient ethanol solution was used to dehydrate the cells and the cells were embedded with epoxy resin. The embedded cells in each group were cut into $70 \mathrm{~nm}$ ultrathin sections, and stained with saturated uranyl acetate and lead acetate solution, then observed and imaged under transmission electron microscope (Hitachi $120 \mathrm{kV}$ transmission electron microscope HT7800; Hitachi, Tokyo, Japan).

Analysis of cell acidic vesicle formation. The HCC-LM3 cells were cultured in high-glucose DMEM supplemented with $10 \% \mathrm{FBS}$ in a humidified atmosphere with $5 \% \mathrm{CO}_{2}$ at $37^{\circ} \mathrm{C}$. Subsequently, the cells in the logarithmic growth phase were plated at a density of $2.5 \times 10^{6}$ cells $/ \mathrm{ml}$ and then at $100 \mu \mathrm{l} /$ well in 
24-well plates. Twelve hours later, the cells in each group were pretreated with autophagy inhibitors 3-MA $(5 \mathrm{mmol} / \mathrm{l})$ and/or CQ $(5 \mu \mathrm{g} / \mathrm{ml})$ for $12 \mathrm{~h}$. In addition, $5 \mathrm{ml}$ DMEM plus $10 \%$ FBS was injected into culture plates in the control group, $5 \mathrm{ml}$ 5 -FU $(186 \mu \mathrm{g} / \mathrm{ml})$ was injected into culture plates in the 5-FU group, $5 \mathrm{ml}$ bufalin $(0.12 \mu \mathrm{g} / \mathrm{ml})$ was injected into culture plates in the bufalin, the bufalin +3-MA, the bufalin +CQ and the bufalin +3-MA + CQ groups. The cells in each group were cultured in a humidified atmosphere with $5 \% \mathrm{CO}_{2}$ at $37^{\circ} \mathrm{C}$ for $24 \mathrm{~h}$. The cells in each group were collected by centrifugation $\left(2,504 \mathrm{x} \mathrm{g}\right.$ at $4^{\circ} \mathrm{C}$ for $\left.10 \mathrm{~min}\right)$ and stained with 5001 acridine orange solution (1acrml) for $5 \mathrm{~min}$; a portion of the HCC-LM3 cells in each group were rinsed with 0.01 M PBS three times. Then the HCC-LM3 cell in each group were observed under the fluorescence microscope (Olympus bioluminescence microscope BX53; Olympus Corp., Tokyo, Japan), and imaged randomly at 5 visual fields. The red fluorescence intensity was assesse by the ImageJ software (V1.48u; National Institutes of Health, Bethesda, MD, USA).

In addition, a part of the HCC-LM3 cells in each group was rinsed with 0.01 M PBS three times. The cells in each group were digested with trypsin for $20 \mathrm{sec}$, the digestion was terminated with $1 \mathrm{ml} 0.01 \mathrm{M}$ PBS containing 5\% serum. The cells in each group were collected by centrifugation $(402 \mathrm{x} \mathrm{g}$ at $4^{\circ} \mathrm{C}$ for $5 \mathrm{~min}$ ) and resuspended in the $0.5 \mathrm{ml} 0.01 \mathrm{M} \mathrm{PBS}$ containing $5 \%$ serum. The fluorescence intensity at $488 \mathrm{~nm}$ was evaluated by flow cytometry; the fluorescence intensity is expressed by FL3/FL1.

Protein expression assay with western blot analysis. HCC-LM3 cells were cultured in high-glucose DMEM supplemented with $10 \% \mathrm{FBS}$ in a humidified atmosphere with $5 \% \mathrm{CO}_{2}$ at $37^{\circ} \mathrm{C}$. Subsequently, the cells in the logarithmic growth phase were plated at a density of $1.5 \times 10^{5}$ cells $/ \mathrm{ml}$, and then $100 \mu \mathrm{l} /$ well in 6 -well plates. Twelve hours later, the cells in each group were pretreated with autophagy inhibitors 3 -MA $(5 \mathrm{mmol} / \mathrm{l})$ and or CQ $(5 \mu \mathrm{g} / \mathrm{ml})$ for $12 \mathrm{~h}$. In addition, $5 \mathrm{ml} 5$-FU $(186 \mu \mathrm{g} / \mathrm{ml})$ was injected into culture plates in the 5 -FU group, $5 \mathrm{ml}$ bufalin $(0.12 \mu \mathrm{g} / \mathrm{ml})$ was injected into culture plates in the bufalin, the bufalin +3-MA, the bufalin + CQ and the bufalin +3-MA + CQ groups. The cells in each group were cultured in a humidified atmosphere with $5 \% \mathrm{CO}_{2}$ at $37^{\circ} \mathrm{C}$ for 12,24 and $48 \mathrm{~h}$. The cells in each group were collected by centrifugation $(2,504 \mathrm{x} \mathrm{g}$ at $4^{\circ} \mathrm{C}$ for $10 \mathrm{~min}$ ) and the proteins of cells in each group were obtained with cell lysis solution. Using western blotting, the protein expression of LC, LC3-II, P62 and Beclin-1 was detected in the HCC-LM3 cells of each group.

Statistical analysis. Data were analyzed by analysis of variance using SPSS 18.0 (SPSS, Inc., Chicago, IL, USA) and GraphPad Prism 5 (SAS Institute, Inc., Cary, NC, USA). All data are presented as the mean \pm SD. The inhibition rate and percentage were calculated using $\chi^{2}$ test. One-way ANOVA test or Student's t-test were used to analyze the other data. P-values $<0.05$ were considered to indicate a statistically significant difference.

\section{Results}

The effect of bufalin combined with autophagy inhibitors on the proliferation of liver cancer cells. Compared with

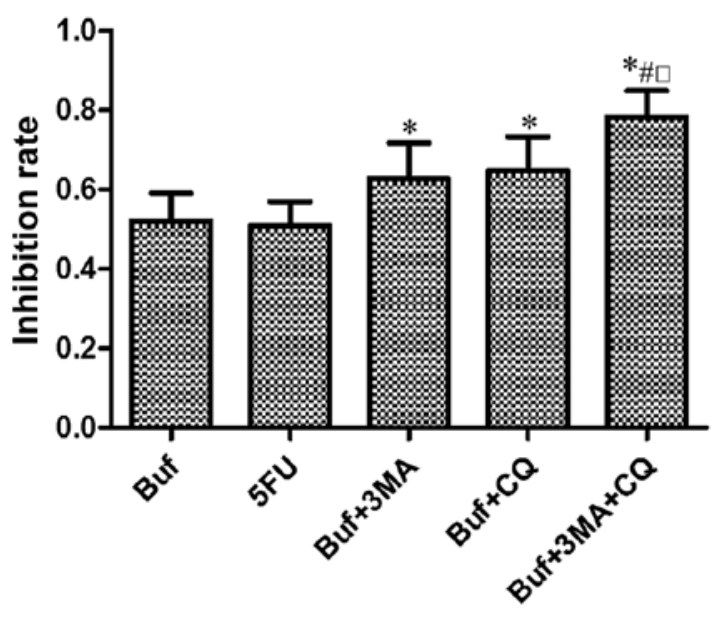

Figure 1 . The inhibitory effect of bufalin combined with autophagy inhibitors on the growth of HCC-LM3 cells for $24 \mathrm{~h}$. The drug concentration of 3-MA, $\mathrm{CQ}, 5-\mathrm{FU}$ and bufalin was $5 \mathrm{mmol} / 1,5,186$ and $0.12 \mu \mathrm{g} / \mathrm{ml}$, respectively. The autophagy inhibitors 3-MA and/or CQ significantly enhanced the inhibitory effect of bufalin on the growth of HCC-LM3 cells when the 3-MA and/or CQ was used in combination with bufalin for $24 \mathrm{~h} .{ }^{*} \mathrm{P}<0.05 \mathrm{vs}$. the bufalin group $(\mathrm{F}=6.58, \mathrm{P}<0.05) ;{ }^{\#} \mathrm{P}<0.05$ vs. the bufalin +3 -MA group $(\mathrm{F}=6.58, \mathrm{P}<0.05)$; ${ }^{\mathrm{P}}<0.05$ vs. the bufalin $+\mathrm{CQ}$ group $(\mathrm{F}=6.58, \mathrm{P}<0.05)$.

the control group, bufalin significantly inhibited the growth of HCC-LM3 cells. Compared with the bufalin group, autophagy inhibitors 3-MA or CQ significantly enhanced the inhibitory effect of bufalin on the growth of HCC-LM3 cells. The inhibitory effect of bufalin combined with 3-MA and CQ on the growth of HCC-LM3 cells was strongest $(\mathrm{F}=6.58$, $\mathrm{P}<0.05)$. There was no significant difference of the inhibitory effect on the growth of HCC-LM3 cells between the bufalin + 3-MA group and the bufalin + CQ group $(\mathrm{F}=6.58$, $\mathrm{P}>0.05$ ) (Fig. 1).

The effect of bufalin combined with autophagy inhibitors on the formation of autophagosomes in liver cancer cells. Compared with the control group, bufalin induced the increase of autophagosomes in HCC-LM3 cells. After the HCC-LM3 cells were pretreated with the autophagy inhibitors 3-MA or $\mathrm{CQ}$ for $12 \mathrm{~h}$, the autophagosomes induced by bufalin for $24 \mathrm{~h}$ in HCC-LM3 cells decreased significantly $(\mathrm{F}=13.27, \mathrm{P}<0.05)$. This finding indicated that the autophagy inhibitors effectively inhibited the autophagosome formation in HCC-LM3 cells induced by bufalin (Fig. 2 and Table I).

The effect of bufalin combined with autophagy inhibitors on the formation of acidic vesicles in liver cancer cells. Compared with the control group, bufalin induced the increase of acidic vesicles in HCC-LM3 cells. After the HCC-LM3 cells were pretreated with autophagy inhibitors 3-MA or CQ for $12 \mathrm{~h}$, the acidic vesicles induced by bufalin for $24 \mathrm{~h}$ in HCC-LM3 cells decreased significantly $(\mathrm{F}=24.58, \mathrm{P}<0.05)$. There was no significant difference among the bufalin $+3-\mathrm{MA}$, the bufalin + CQ and the bufalin +3-MA + CQ groups $(\mathrm{F}=24.58$, $\mathrm{P}>0.05)$. This finding indicated that the autophagy inhibitors effectively inhibited the acidic vesicle formation in HCC-LM3 cells induced by bufalin, however the inhibitory effect of autophagy inhibitors was irrelevant to the type of autophagy inhibitors (Figs. 3 and 4; Table II). 


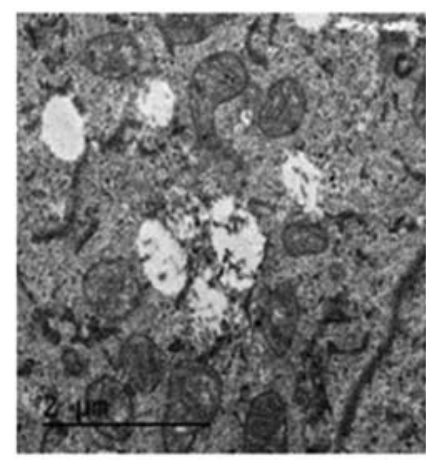

Control

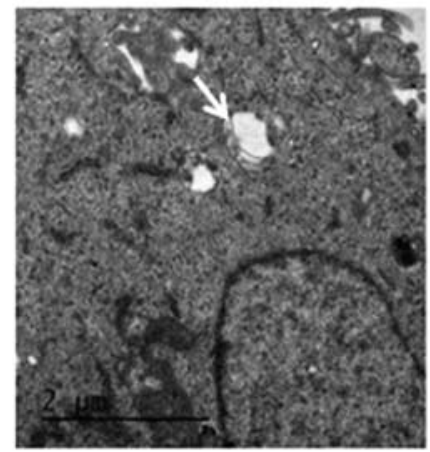

Buf+3MA

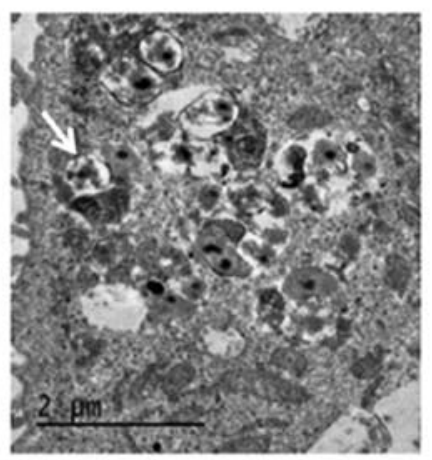

Buf

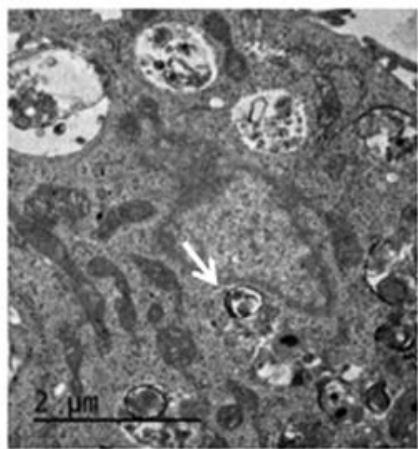

Buf + CQ

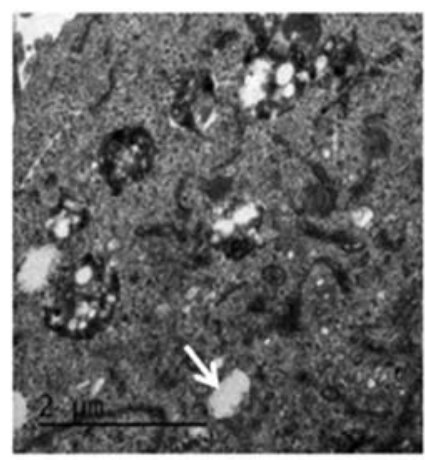

5FU

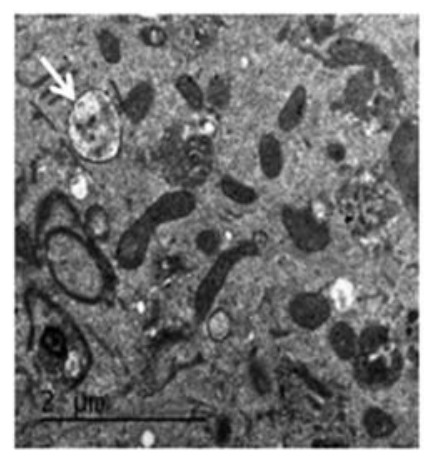

Buf $+3 M A+C Q$

Figure 2. The autophagosome formation in HCC-LM3 cells when bufalin alone or in combination with autophagy inhibitors is used for $24 \mathrm{~h}$ [transmission electron microscope (TEM), magnification x11.500]. The autophagosome in HCC-LM3 cells is indicated with white arrows. The drug concentration of 3-MA, CQ, 5-FU and bufalin was $5 \mathrm{mmol} / 1,5,186$ and $0.12 \mu \mathrm{g} / \mathrm{ml}$, respectively. Bufalin induced the increase of autophagosomes in HCC-LM3 cells (Buf, bufalin group). Following the pretreatment of HCC-LM3 cells with autophagy inhibitors, the autophagosomes induced by bufalin in HCC-LM3 cells decreased significantly (in buf $+3-\mathrm{MA}$, buf $+\mathrm{CQ}$, buf $+3-\mathrm{MA}+\mathrm{CQ}$ groups).

Table I. Influence of bufalin alone or combined with autophagy inhibitors on the formation of autophagosome in HCC-LM3 cells for $24 \mathrm{~h}($ mean $\pm \mathrm{SD}, \mathrm{n}=3)$.

\begin{tabular}{lcccccc}
\hline & $\begin{array}{c}\text { Control } \\
\text { group }\end{array}$ & $\begin{array}{c}\text { Bufalin } \\
\text { group }\end{array}$ & $\begin{array}{c}\text { 5-FU } \\
\text { group }\end{array}$ & $\begin{array}{c}\text { Buf+3-MA } \\
\text { group }\end{array}$ & $\begin{array}{c}\text { Buf }+\mathrm{CQ} \\
\text { group }\end{array}$ & $\begin{array}{c}\text { Buf }+3-\mathrm{MA}+\mathrm{CQ} \\
\text { group }\end{array}$ \\
\hline $\begin{array}{l}\text { No. of autophagosomes } \\
\text { in HCC-LM3 cells }\end{array}$ & $0.00 \pm 0.00^{\mathrm{a}}$ & $13.60 \pm 4.12$ & $11.67 \pm 3.10$ & $2.53 \pm 3.86^{\mathrm{a}}$ & $4.28 \pm 3.22^{\mathrm{a}}$ & $3.12 \pm 2.71^{\mathrm{a}}$ \\
\hline
\end{tabular}

${ }^{\mathrm{a}} \mathrm{P}<0.05$ vs. the bufalin group. Buf, bufalin; 5-FU, 5-fluorouracil; 3-MA, 3-methyladenine; CQ, chloroquine.

The effect of bufalin combined with autophagy inhibitors on the expression of autophagy-related proteins in liver cancer cells for $12 \mathrm{~h}$. Compared with the bufalin +3-MA group, the expression of LC3-I in HCC-LM3 cells significantly decreased after bufalin alone or in combination with autophagy inhibitors was used to treat the HCC-LM3 cells for $12 \mathrm{~h}(\mathrm{~F}=2.37$, $\mathrm{P}<0.05)$. There was no significant difference of the expression of LC3-I in the HCC-LM3 cells between the other groups $(\mathrm{F}=2.37, \mathrm{P}>0.05)$. Compared with the bufalin group, the expression of LC3-II in HCC-LM3 cells significantly decreased in the bufalin +3-MA group. Compared with the bufalin and bufalin +3-MA group, the expression of LC3-II in HCC-LM3 cells significantly increased in the bufalin +CQ group. Compared with the bufalin $+\mathrm{CQ}$ group, the expression of LC3-II in HCC-LM3 cells significantly decreased in the bufalin + 3-MA + CQ group ( $\mathrm{F}=2.63, \mathrm{P}<0.05)$. Compared with the control group, the P62 expression of HCC-LM3 cells significantly decreased in the bufalin group. Compared with the bufalin, the bufalin +3-MA and the bufalin+CQ groups, the expression of P62 in HCC-LM3 cells significantly increased in the bufalin $+3-\mathrm{MA}+\mathrm{CQ}$ group $(\mathrm{F}=3.63$, $\mathrm{P}<0.05)$. Compared with the control group, the expression of Beclin-1 in HCC-LM3 cells significantly increased in the bufalin group. Compared with the bufalin group, the expression of Beclin-1 in HCC-LM3 cells significantly decreased in the bufalin + 3-MA and the bufalin + 3-MA+CQ groups. Compared with the bufalin $+3-\mathrm{MA}$ group, the expression of Beclin-1 in HCC-LM3 cells significantly increased in the 

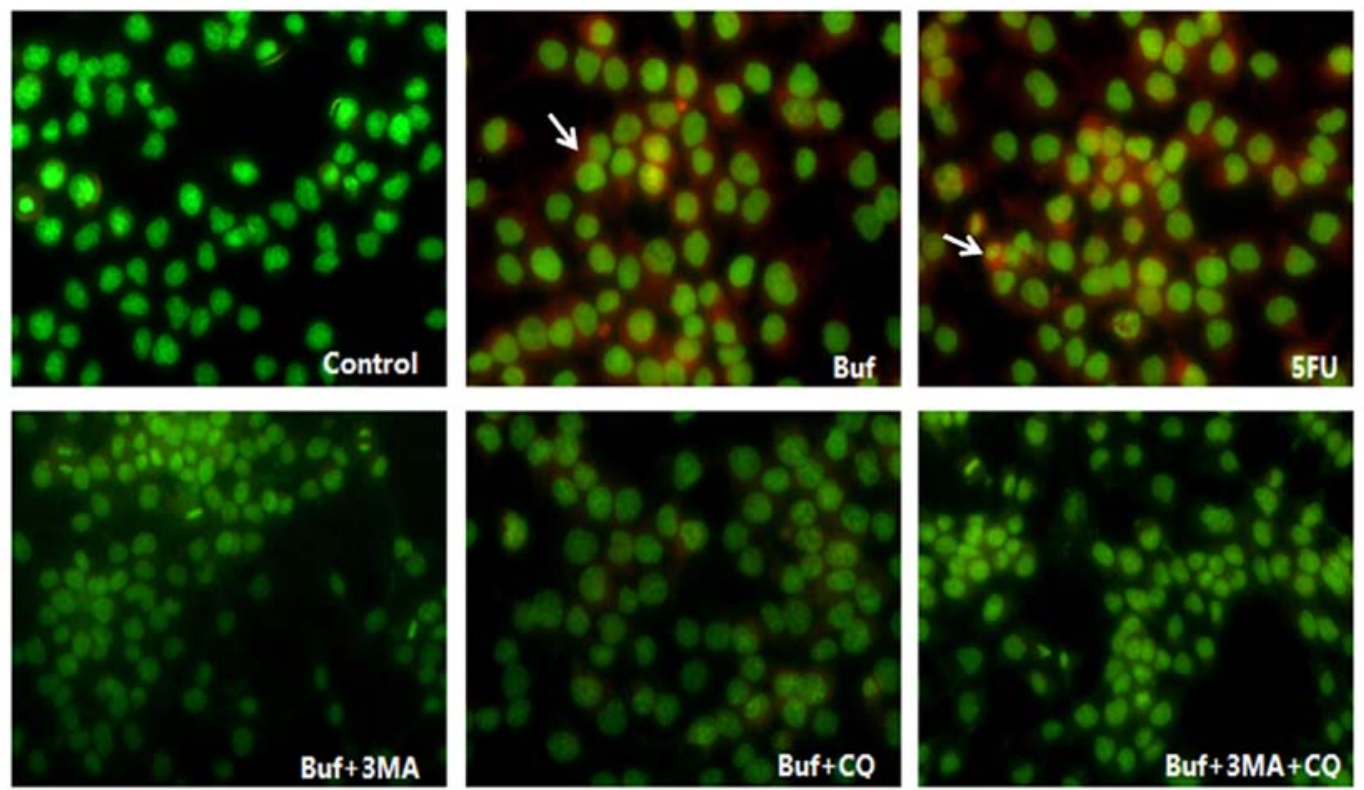

Figure 3. Acidic vesicle formation in HCC-LM3 cells when bufalin alone or in combination with autophagy inhibitors is used for $24 \mathrm{~h}$ (red fluorescence, magnification $\mathrm{x} 200$ ). The drug concentration of 3-MA, CQ, 5-FU and bufalin was $5 \mathrm{mmol} / 1,5,186$ and $0.12 \mu \mathrm{g} / \mathrm{ml}$, respectively. The acidic vesicles in HCC-LM3 cells are indicated with white arrows. Bufalin induced the increase of acidic vesicles in HCC-LM3 cells in the bufalin group (red fluorescence intensity in the bufalin vs. the control group, $\mathrm{F}=13.10, \mathrm{P}<0.05)$. After the HCC-LM3 cells were pretreated with autophagy inhibitors, the acidic vesicles in HCC-LM3 cells decreased significantly in the bufalin +3-MA, the bufalin + CQ and the bufalin +3-MA+CQ group (vs. the bufalin group; $\mathrm{F}=13.10, \mathrm{P}<0.05$ ), however, there was no significant difference of the acidic vesicles in HCC-LM3 cells between the bufalin $+3-\mathrm{MA}$, the bufalin + CQ and the bufalin $+3-\mathrm{MA}+\mathrm{CQ}$ groups (vs the bufalin +3-MA+CQ group; $F=13.10, P<0.05$ ).

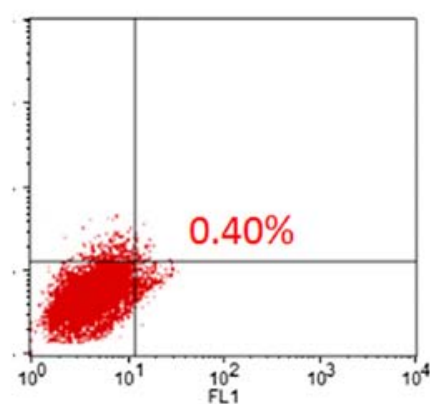

Control

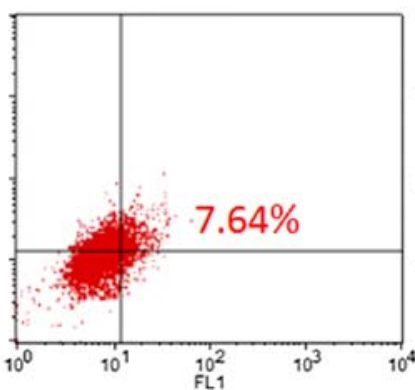

Buf+3MA

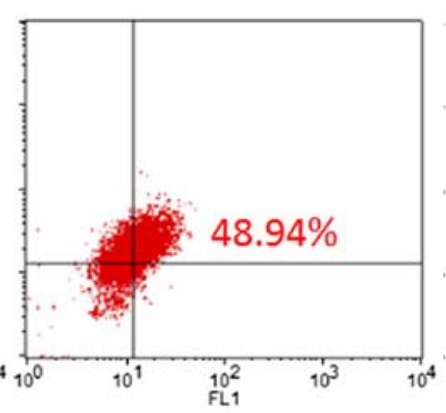

Buf

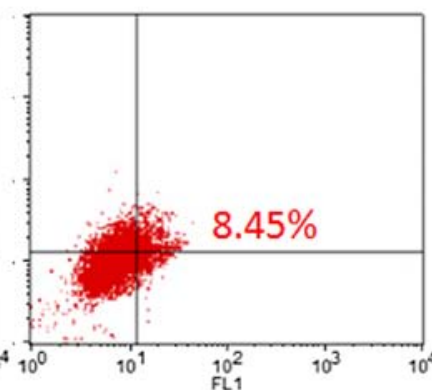

Buf $+\mathrm{CQ}$

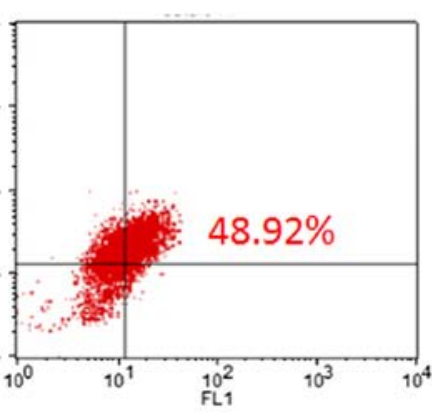

5FU

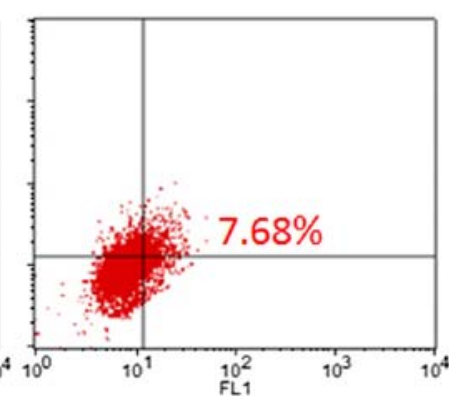

Buf +3MA+CQ

Figure 4. The percentage of HCC-LM3 cells containing acidic vesicles detected by flow cytometry following treatment with bufalin alone or in combination with autophagy inhibitors for $24 \mathrm{~h}$. The drug concentration of 3-MA, CQ, 5-FU and bufalin was $5 \mathrm{mmol} / 1,5,186$ and $0.12 \mu \mathrm{g} / \mathrm{ml}$, respectively. Compared with the control group, the percentage of HCC-LM3 cells containing acidic vesicles significantly increased when bufalin was used for $24 \mathrm{~h}$ ( 48.9 vs. $0.40 \%$, $\mathrm{F}=24.58, \mathrm{P}<0.05$. Compared with the bufalin group, the percentage of liver cancer cells containing acidic vesicles in the bufalin $+3-\mathrm{MA}$, the bufalin $+\mathrm{CQ}$ and the bufalin + 3-MA + CQ group significantly decreased when bufalin was used for $24 \mathrm{~h}(48.9$ vs. 7.64, 8.45 and 7.68\%; F=24.58, P<0.05, Table III).

bufalin $+\mathrm{CQ}$ group. Compared with the bufalin +CQ group, the expression of Beclin-1 in HCC-LM3 cells significantly decreased in the bufalin $+3-\mathrm{MA}+\mathrm{CQ}$ group $(\mathrm{F}=4.33$, $\mathrm{P}<0.05$ ) (Fig. 5). 
The effect of bufalin combined with autophagy inhibitors on the expression of autophagy-related proteins in liver cancer cells for $24 \mathrm{~h}$. Compared with the control group, the expression of LC3-I in HCC-LM3 cells significantly decreased in the bufalin group after bufalin alone or in combination with autophagy inhibitors was used to treat the HCC-LM3 cells for $24 \mathrm{~h}$. Compared with the bufalin group, the expression of LC3-I in HCC-LM3 cells significantly increased in the bufalin + CQ and the bufalin +3-MA + CQ groups $(\mathrm{F}=5.60$, $\mathrm{P}<0.05)$. Compared with the control group, the expression of LC3-II in HCC-LM3 cells significantly increased in the bufalin group. Compared with the bufalin group, the expression of LC3-II in HCC-LM3 cells significantly decreased in the bufalin +3-MA group and the bufalin +3-MA + CQ group. Compared with the bufalin +3-MA group, the expression of LC3-II in HCC-LM3 cells significantly increased in the bufalin + CQ group $(\mathrm{F}=4.97, \mathrm{P}<0.05)$. Compared with the control group, the expression of P62 in HCC-LM3 cells significantly decreased in the bufalin group. Compared with the bufalin group, the expression of P62 in HCC-LM3 cells significantly increased in the bufalin $+3-\mathrm{MA}$, the bufalin $+\mathrm{CQ}$ and the bufalin +3-MA + CQ groups $(\mathrm{F}=5.92, \mathrm{P}<0.05)$. Compared with the control group, the expression of Beclin-1 in HCC-LM3 cells significantly increased in the bufalin group. Compared with the bufalin group, the expression of Beclin-1 in HCC-LM3 cells significantly decreased in the bufalin +3-MA group. Compared with the bufalin +3-MA group, the expression of Beclin-1 in HCC-LM3 cells significantly increased in the bufalin $+\mathrm{CQ}$ and the bufalin $+3-\mathrm{MA}+\mathrm{CQ}$ groups $(\mathrm{F}=5.33$, $\mathrm{P}<0.05$ ) (Fig. 6).

The effect of bufalin combined with autophagy inhibitors on the expression of autophagy-related proteins in liver cancer cells for $48 \mathrm{~h}$. Compared with the bufalin group, the LC3-I expression of HCC-LM3 cells significantly increased in the bufalin +3-MA group and the bufalin + CQ group after bufalin alone or/and in combination with autophagy inhibitors was used to treat the HCC-LM3 cells for $48 \mathrm{~h}$. Compared with the bufalin + CQ group, the expression LC3-I in HCC-LM3 cells significantly decreased in the bufalin +3-MA+CQ group $(\mathrm{F}=1.32, \mathrm{P}<0.05)$. Compared with the control group, the expression of LC3-II in HCC-LM3 cells significantly increased in the bufalin group. Compared with the bufalin group, the expression of LC3-II in HCC-LM3 cells significantly decreased in the bufalin $+3-\mathrm{MA}$ group $(\mathrm{F}=1.96$, $\mathrm{P}<0.05)$. Compared with the control group, the expression of P62 in HCC-LM3 cells significantly decreased in the bufalin group. Compared with the bufalin group, the expression of P62 in HCC-LM3 cells significantly increased in the bufalin + 3-MA + $\mathrm{CQ}$ group $(\mathrm{F}=5.37, \mathrm{P}<0.05)$. Compared with the bufalin group, the expression of Beclin-1 in HCC-LM3 cells significantly decreased in the bufalin $+3-\mathrm{MA}$ and the bufalin + 3-MA + CQ groups and the expression Beclin-1 in HCC-LM3 cells significantly increased in the bufalin +CQ group. Compared with the bufalin +3-MA group, the expression of Beclin-1 in HCC-LM3 cells significantly increased in the bufalin $+\mathrm{CQ}$ group. Compared with the bufalin +CQ group, the expression of Beclin-1 in HCC-LM3 cells significantly decreased in the bufalin +3-MA+CQ group $(\mathrm{F}=15.84$, $\mathrm{P}<0.05$ ) (Fig. 7). 
Table III. Influence of bufalin alone and combined with autophagy inhibitors on the formation of acidic vesicles in HCC-LM3 cells for $24 \mathrm{~h}($ mean $\pm \mathrm{SD}, \mathrm{n}=3)$.

\begin{tabular}{lcccccc}
\hline & $\begin{array}{c}\text { Control } \\
\text { group }\end{array}$ & $\begin{array}{c}\text { Bufalin } \\
\text { group }\end{array}$ & $\begin{array}{c}5-\mathrm{FU} \\
\text { group }\end{array}$ & $\begin{array}{c}\text { Buf+3MA } \\
\text { group }\end{array}$ & $\begin{array}{c}\text { Buf+CQ } \\
\text { group }\end{array}$ & $\begin{array}{c}\text { Buf+3MA+CQ } \\
\text { group }\end{array}$ \\
\hline $\begin{array}{l}\text { Percentage of HCC-LM3 cells } \\
\text { containing acidic vesicles }\end{array}$ & $0.40 \pm 0.38^{\mathrm{a}}$ & $48.94 \pm 12.46$ & $48.92 \pm 13.69$ & $7.64 \pm 2.12^{\mathrm{a}, \mathrm{b}}$ & $8.45 \pm 3.55^{\mathrm{a}, \mathrm{b}}$ & $7.68 \pm 2.37^{\mathrm{a}, \mathrm{b}}$ \\
\hline
\end{tabular}

${ }^{\mathrm{a}} \mathrm{P}<0.05$ vs. the bufalin group; ${ }^{\mathrm{b}} \mathrm{P}>0.05$ vs. the Buf + 3MA+CQ group. 5-FU, 5-fluorouracil; 3-MA, 3-methyladenine; $\mathrm{CQ}$, chloroquine.

A

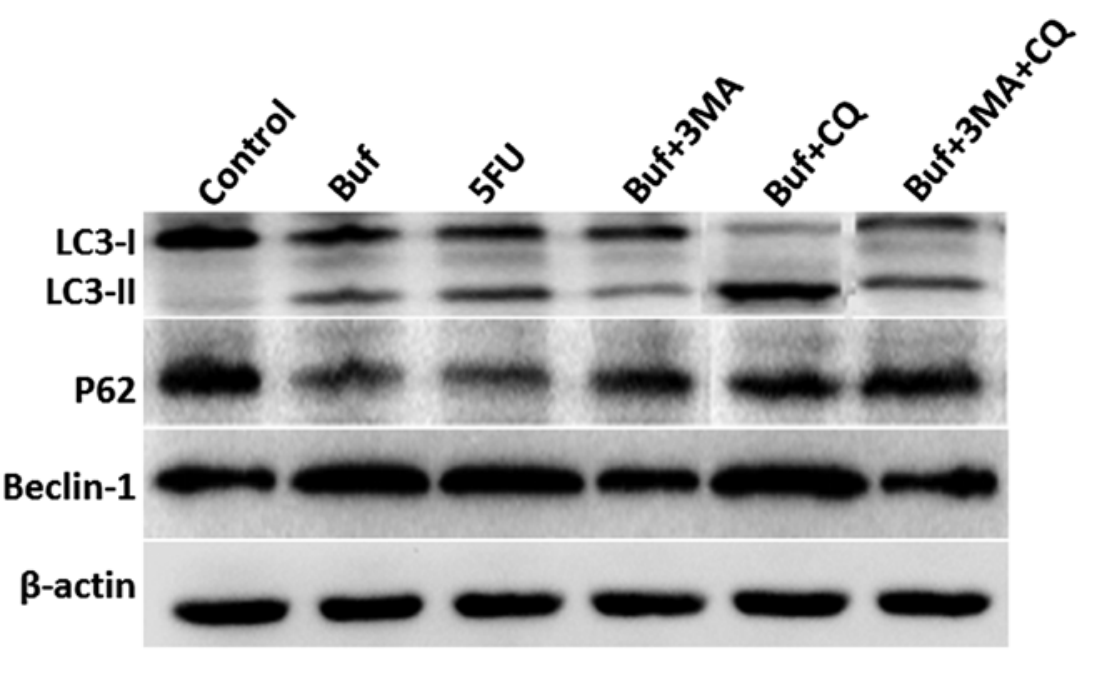

B
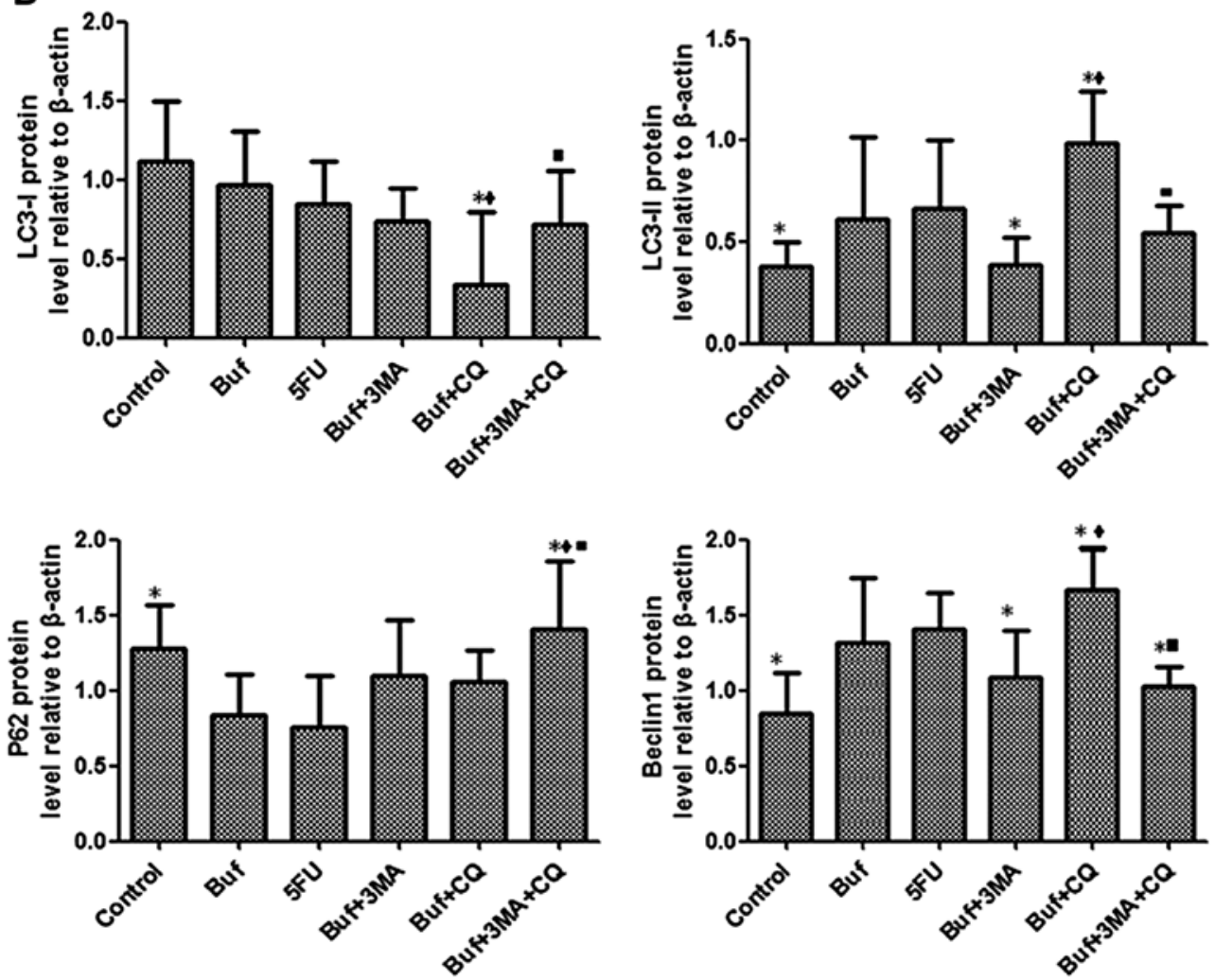

Figure 5. Bufalin affects cell autophagy by influencing the expression of autophagy related proteins in liver cancer cells at $12 \mathrm{~h}$. (A) The expression of LC3-I, LC3-II, P62 and Beclin-1 in HCC-LM3 cells was detected by western blot analysis after bufalin alone or in combination with autophagy inhibitors was used to treat the HCC-LM3 cells for $12 \mathrm{~h}$. (B) The different expression of LC3-I, LC3-II, P62 and Beclin-1 in HCC-LM3 cells was analyzed after bufalin alone or in combination with autophagy inhibitors was used to treat the HCC-LM3 cells for $12 \mathrm{~h}$. The drug concentration of 3-MA, CQ, 5-FU and bufalin was $5 \mathrm{mmol} / 1$, 5,186 and $0.12 \mu \mathrm{g} / \mathrm{ml}$, respectively. ${ }^{*} \mathrm{P}<0.05$ vs. the bufalin group; ${ }^{\bullet} \mathrm{P}<0.05$, the bufalin $+3-\mathrm{MA}$ vs. the bufalin $+\mathrm{CQ}$, the bufalin $+3-\mathrm{MA}+\mathrm{CQ}$ group; ${ }^{\mathrm{P}} \mathrm{P}<0.05$, the bufalin $+\mathrm{CQ}$ vs. the bufalin +3-MA+CQ group. 
A

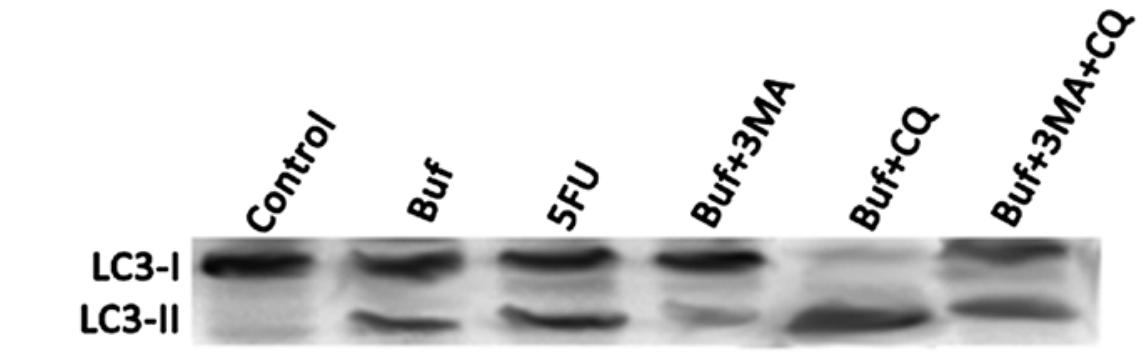

P62

Beclin-1

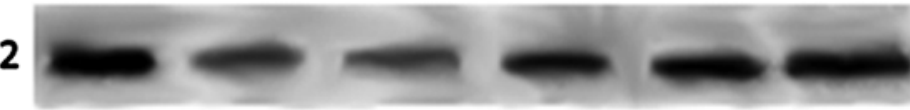

\section{B-actin}
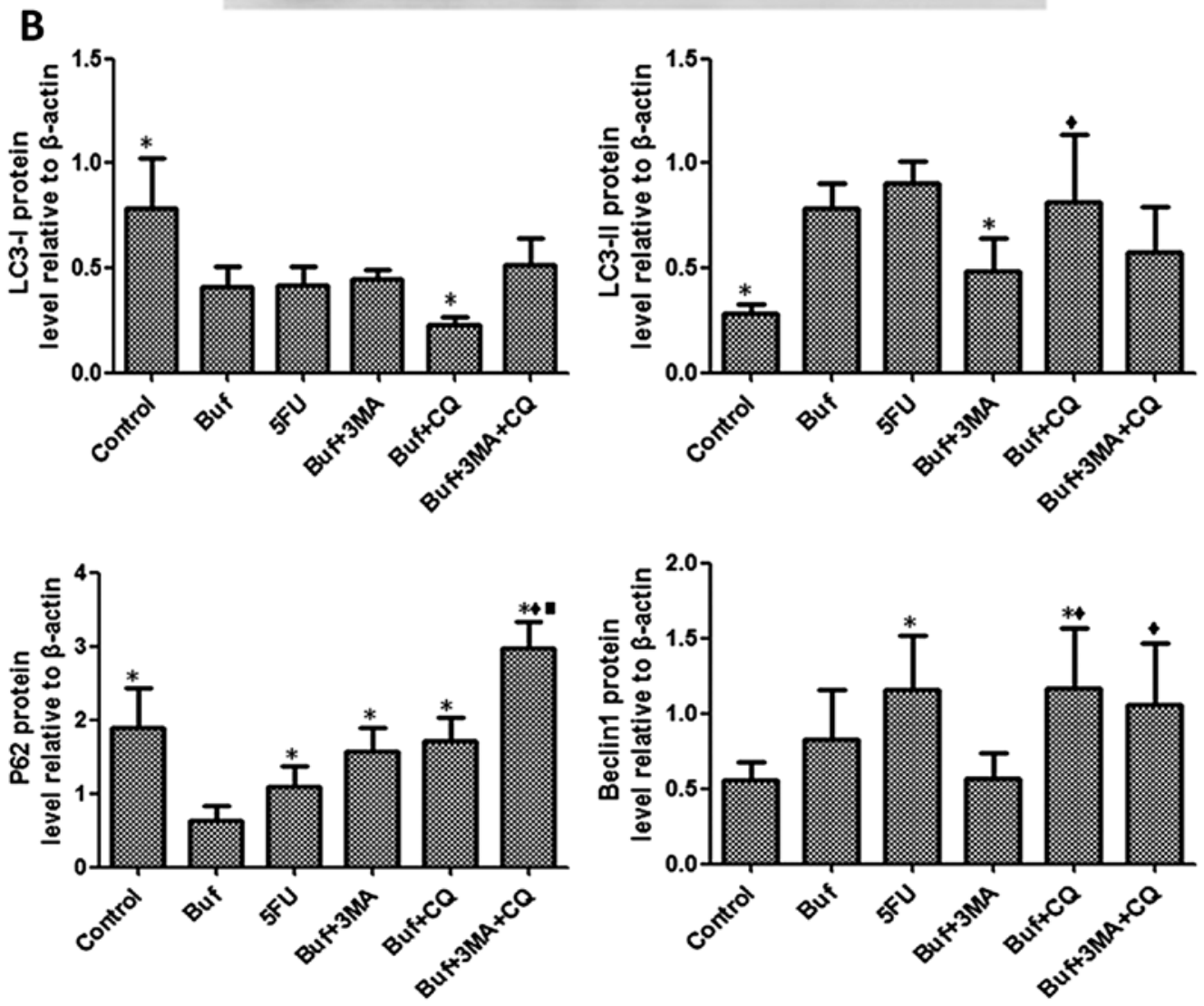

Figure 6. Bufalin affects cell autophagy by influencing the expression of autophagy related proteins in liver cancer cells at 24 h. (A) The expression of LC3-I, LC3-II, P62 and Beclin-1 in HCC-LM3 cells was detected by western blot analysis after bufalin alone or in combination with autophagy inhibitors was used to treat the HCC-LM3 cells for $24 \mathrm{~h}$. (B) The different expression of LC3-I, LC3-II, P62 and Beclin-1 in HCC-LM3 cells was analyzed after bufalin alone or and in combination with autophagy inhibitors was used to treat the HCC-LM3 cells for $24 \mathrm{~h}$. The drug concentrations of 3-MA, CQ, 5-FU and bufalin were $5 \mathrm{mmol} / 1,5,186$ and $0.12 \mu \mathrm{g} / \mathrm{ml}$, respectively. ${ }^{*} \mathrm{P}<0.05$ vs. the bufalin group; ${ }^{\bullet} \mathrm{P}<0.05$, the bufalin $+3-\mathrm{MA}$ vs. the bufalin $+\mathrm{CQ}$, the bufalin $+3-\mathrm{MA}+\mathrm{CQ}$ groups; - $<0.05$, the bufalin + CQ vs. the bufalin +3-MA+CQ group.

\section{Discussion}

Autophagy can lead to cancer cell death and inhibit tumor growth. However, autophagy can also destroy the organelles and proteins, enhance the ability of tumor cell to resist to severe environmental changes and protect tumor cells, thereby promoting tumor growth. Autophagy plays a dual role in the protection and inhibition of the proliferation of liver cancer cells and its mechanism involves the interaction between multiple genes and factors. LC3, P62 and Beclin-1 are closely related to autophagy proteins. When autophagy occurs in cells, LC3-I combines with phosphatidylethanolamine on the surface of autophagic vacuoles to form LC3-II. LC3-II binds specifically to the surface of the autophagic vesicle membrane and is involved in the regulation of autophagic vesicle formation (13). At the late stage of autophagy, the autophagosome fuses with lysosome to degrade LC3-II by hydrolases $(14,15)$. P62 is the substrate and regulatory protein 

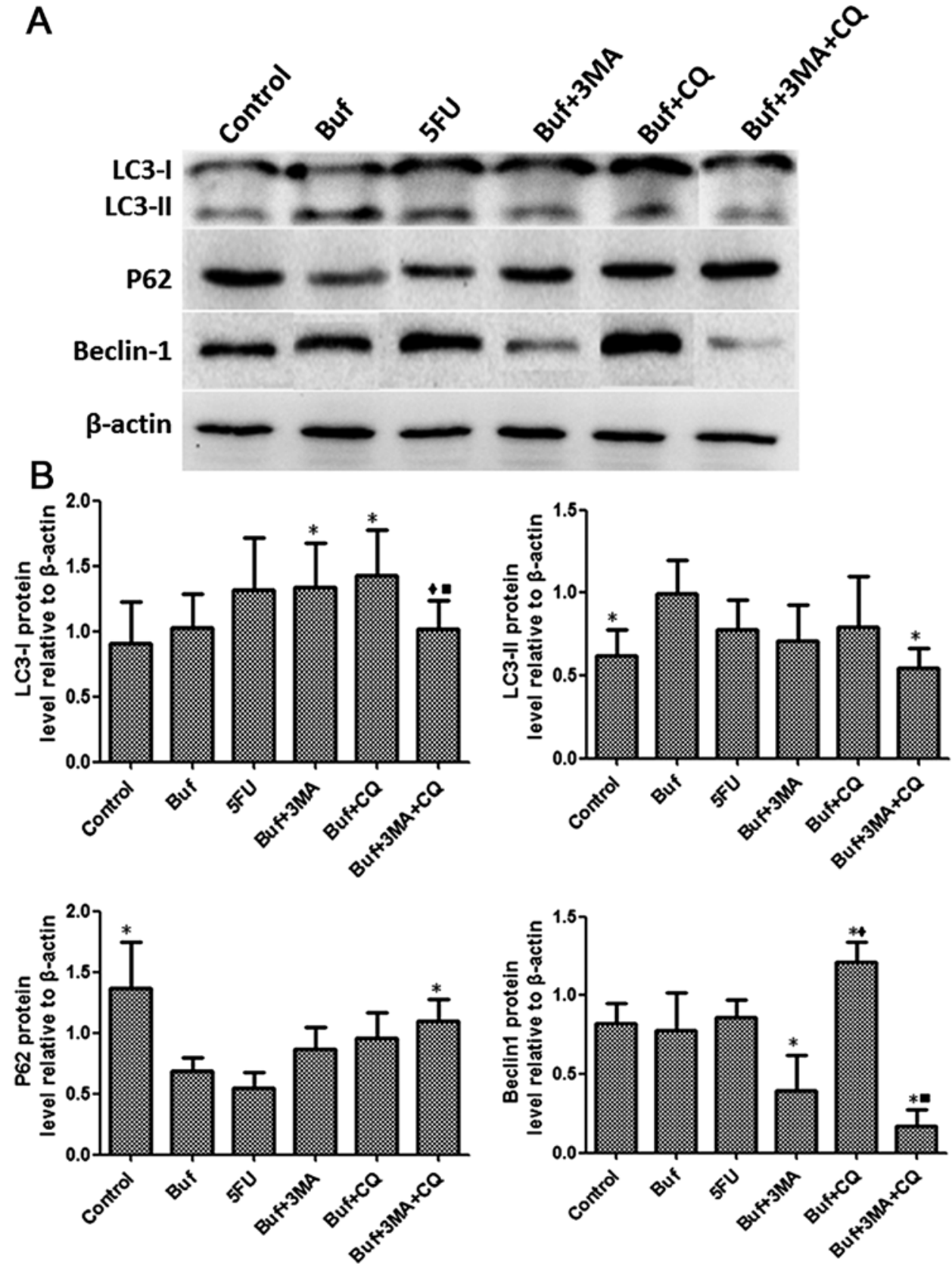

Figure 7. Bufalin affects cell autophagy by influencing the expression of autophagy related proteins in liver cancer cells at $48 \mathrm{~h}$. (A) The expression of LC3-I, LC3-II, P62 and Beclin-1 in HCC-LM3 cells was detected by western blot analysis after bufalin alone or/and in combination with autophagy inhibitors was used to treat HCC-LM3 cells for $48 \mathrm{~h}$. (B) The different expression of LC3-I, LC3-II, P62 and Beclin-1 in HCC-LM3 cells was analyzed after bufalin alone or/and in combination with autophagy inhibitors was used to treat HCC-LM3 cells for $48 \mathrm{~h}$. The drug concentration of 3-MA, CQ, 5-FU and bufalin was $5 \mathrm{mmol} / 1,5,186$ and $0.12 \mu \mathrm{g} / \mathrm{ml}$, respectively. ${ }^{*} \mathrm{P}<0.05$ vs. the bufalin group; ${ }^{\oplus} \mathrm{P}<0.05$, the bufalin $+3-\mathrm{MA}$ vs. the bufalin $+\mathrm{CQ}$, the bufalin $+3-\mathrm{MA}+\mathrm{CQ}$ group; $-\mathrm{P}<0.05$, the bufalin $+\mathrm{CQ}$ vs. the bufalin $+3-\mathrm{MA}+\mathrm{CQ}$ group.

of autophagy (16). At the initial stage of autophagy, misfolded proteins are not able to be normally transported and aggregate in the cytoplasm to form the aggresomes. The aggresomes undergo ubiquitination and recruit greater polymers through the P62 protein. Abnormal aggregation in tumor tissue can be recognized by regulatory proteins or receptors that bind to the Atg8 protein $(13,17-19)$. Autophagy can inhibit tumor growth by scavenging the P62 protein in mice with autophagy defects (13). Beclin-1 is an essential molecule in the formation of autophagosomes, which regulates the formation and maturation of autophagosomes in mammals. Ding et al (2) observed that the expression of autophagy-related protein
Beclin-1 in HCC tissues was significantly lower than that in peripheral normal tissues and the expression level of Beclin-1 was correlated with the extent of malignancy of HCC. Duan et al (20) observed that Beclin-1 upregulated the expression of PI3KC3 and induced autophagy in ovarian cancer cells. Li et al (21) observed that the autophagosomes and LC3-II protein increased significantly in liver cancer cells (HepG2, BEL-7402 cells) and P62 protein decreased significantly after the liver cancer cells were deprived of nutrients in vitro. In addition they observed that the invasive ability of the liver cancer cells was significantly enhanced due to nutritional deprivation. 
Furthermore, 3-MA and CQ are autophagy inhibitors; 3-MA can inhibit the autophagosome formation by inhibiting the intracellular phosphatidylinositol three phosphate kinase. CQ can inhibit the autophagosome formation by inhibiting the proteolytic enzymes of intracellular lysosomes. The present study indicated that bufalin significantly inhibited the growth of liver cancer cells. The inhibitory effect of bufalin was significantly enhanced when combined with autophagy inhibitors 3-MA or CQ. Furthermore, the inhibitory effect of bufalin on the growth of liver cancer cells was strongest when combined with 3-MA and CQ. Bufalin could induce the increase of autophagosomes in HCC-LM3 cells, whereas when the HCC-LM3 cells were pretreated with autophagy inhibitors 3-MA or CQ, the autophagosomes induced by bufalin in HCC-LM3 cells decreased markedly. Bufalin induced the decrease of autolysosomes in HCC-LM3 cells in combination with autophagy inhibitors 3-MA or CQ. This finding indicated that the autophagy inhibitors could effectively inhibit the autophagosome formation induced by bufalin in HCC-LM3 cells. Autophagy is involved in the proliferation of liver cancer cells. The inhibitory effect of bufalin on liver cancer cells could be affected by interfering with autophagy. The autophagy inhibitors could synergistically enhance the inhibitory effect of bufalin on the proliferation of liver cancer cells by interfering with autophagy.

Under normal circumstances, P62 protein locates in a specific site of autophagosomes in early autophagy and is broken down by hydrolases of the lysosomes when autophagolysosomes form. When P62 protein cannot be degraded and begins to accumulate, it indicates that the autophagy process may be inhibited (22). The LC3-I protein can be decomposed to transform into the LC3-I protein when autophagy occurs in cells. The LC3-II protein can be degraded by proteolytic enzymes of the lysosomes when autophagolysosomes form. The increase of the LC3-II protein and the decrease of the LC3-I protein in cells, is an indication that autophagy occurs in cells (23). Beclin-1 binds to different molecules to form a complex that regulates the formation and maturation of autophagosomes. When autophagolysosomes form, Beclin-1 is degraded by proteolytic enzymes of the lysosomes (24). The present study indicated that bufalin upregulated the protein expression of LC3-II and Beclin-1, as well as downregulated the expression of p62 in HCC-LM3 cells. These protein expression changes induced autophagy in HCC-LM3 cells. Combined with autophagy inhibitor 3-MA, bufalin downregulated the protein expression of LC3-II and Beclin-1, and upregulated the expression of p62 in HCC-LM3 cells, thereby inhibited autophagy in HCC-LM3 cells. Combined with autophagy inhibitor $\mathrm{CQ}$, bufalin upregulated the protein expression of LC3-II, Beclin-1 and p62 in HCC-LM3 cells. This observation may be related to the inhibition of proteolytic enzyme activity by $\mathrm{CQ}$, thereby the degradation of proteolytic enzymes on P62, LC3- II and Beclin-1 proteins in HCC-LM3 cells can be inhibited (25). Concerning the inhibitory effect of bufalin on P62, LC3-II and Beclin-1 proteins in HCC-LM3 cells there was no significant difference between the bufalin +3-MA and the bufalin + 3-MA + CQ group. These results indicated that the inhibitory effect of 3-MA on autophagy-related proteins in liver cancer cells could not be enhanced in combination with CQ. The main reason may be that CQ inhibits the autophagolysosome degradation by inhibiting the role of proteolytic enzyme of lysosome, thereby inhibits the final stage of autophagy. Conversely, 3-MA inhibits the phosphatidylinositol three phosphate kinase to block the formation of autophagosomes, thereby inhibits the early stage of autophagy. When the two inhibitors are combined, 3-MA can prevent most of the autophagy from entering the terminal stage, thus preventing CQ from functioning normally $(21,25)$.

In conclusion, the present study indicated that bufalin induced autophagy in liver cancer cells by upregulating the protein expression of LC3-II and Beclin-1 and by downregulating the protein expression of P62. Autophagy inhibitors significantly enhanced the inhibitory effect of bufalin on the growth of liver cancer cells by interfering with the protein expression of LC3-II, Beclin-1 and P62 to inhibit the autophagy of liver cancer cells. These findings indicate that the therapeutic efficacy of bufalin on HCC can be improved through targeting autophagy-related proteins. It provide important theoretical basis on developing molecular targeted drugs for autophagy-related proteins of HCC.

\section{Acknowledgements}

Not applicable.

\section{Funding}

The present study was supported by a grant from the Research Project of Medical Key Specialty of Putuo Sistrict, Shanghai (no. B-162).

\section{Availability of data and materials}

The datasets used during the present study are available from the corresponding author upon reasonable request.

\section{Authors' contributions}

ZPF and QJM conceived and designed the study. ZPF and SX performed the experiments. ZPF and QJM wrote the paper. QJM and LQ reviewed and edited the manuscript. All authors read and approved the manuscript and agree to be accountable for all aspects of the research in ensuring that the accuracy or integrity of any part of the work are appropriately investigated and resolved.

\section{Ethics approval and consent to participate}

All experimental protocols were approved by the Institutional Review Board of the Department of Laboratory Animal Science of the Second Military Medical University (Shanghai, China).

\section{Consent for publication}

Not applicable.

\section{Competing interests}

The authors state that they have no competing interests. 


\section{References}

1. Hale AN, Ledbetter DJ, Gawriluk TR and Rucker EB III Autophagy: Regulation and role in development. Autophagy 9: 951-972, 2013.

2. Ding ZB, Shi YH, Zhou J, Qiu SJ, Xu Y, Dai Z, Shi GM, Wang XY, Ke AW, Wu B, et al: Association of autophagy defect with a malignant phenotype and poor prognosis of hepatocellular carcinoma. Cancer Res 68: 9167-9175, 2008.

3. Du H, Yang W, Chen L, Shi M, Seewoo V, Wang J, Lin A, Liu Z and Qiu W: Role of autophagy in resistance to oxaliplatin in hepatocellular carcinoma cells. Oncol Rep 27: 143-150, 2012.

4. Guo XL, Li D, Hu F, Song JR, Zhang SS, Deng WJ, Sun K, Zhao QD, Xie XQ, Song YJ, et al: Targeting autophagy potentiates chemotherapy-induced apoptosis and proliferation inhibition in hepatocarcinoma cells. Cancer Letter 320: 171-179, 2012.

5. Choi KS: Autophagy and cancer. Exp Mol Med 44: 109-120, 2012.

6. Jiang CL and Zhu YQ: Advances in research on antitumor activity of toads. Nat Product Res Dev 12: 67-72, 2000.

7. Han JT, Chen XY and Xu RC: Advances in pharmacological activities of bufalin. Chin Remed Clin 2: 120-122, 2002.

8. Chen XY, Hu WL, Xu RC, Chen L and Qian J: Effect of bufalin on cytotoxicity and growth related gene expression of human hepatoma cell line SMMC 7721. Chin J Pharmacol Toxicol 15 293-296, 2001

9. Gai JQ, Qin JM and Fan YZ: Experimental study on bufalin inhibiting hepatocellular carcinoma proliferation and invasion. World Chin J Digestol 22: 1921-1927, 2014

10. Sheng X, Sun X, Sun K, Sui H, Qin J and Li Q: Inhibitory effect of bufalin combined with Hedgehog signaling pathway inhibitors on proliferation and invasion and metastasis of liver cancer cells. Int J Oncol 49: 1513-1524, 2016.

11. Change J, Sun K, Sheng X and Qin JM: Experimental study of bufalin on inhibiting cell proliferation and apoptosis in liver can cer cells with high metastatic potential. Chin J Exp Surg 32: 2388-2391, 2015

12. Gai JQ, Sheng X, Qin JM, Sun K, Zhao W and Ni L: The effect and mechanism of bufalin on regulating hepatocellular carcinoma cell invasion and metastasis via Wnt/ $\beta$-catenin signaling pathway. Int J Oncol 48: 338-348, 2016.

13. Pankiv S, Clausen TH, Lamark T, Brech A, Bruun JA, Outzen H, Øvervatn A, Bjørkøy G and Johansen T: p62/SQSTM1 binds directly to Atg8/LC3 to facilitate degradation of ubiquitinated protein aggregates by autophagy. J Biol Chem 282: 24131-24145, 2007.
14. Levine B and Yuan J: Autophagy in cell death: An innocent convict? J Clin Invest 115: 2679-2688, 2005.

15. Tanida I, Nishitani T, Nemoto T, Ueno T and Kominami E: Mammalian Apg12p, but not the Apg12p.Apg5p conjugate, facilitates LC3 processing. Biochem Biophys Res Commun 296: 1164-1170, 2002

16. Tanida I, Ueno T and Kominami E: In vitro assays of lipidation of Mammalian Atg8 homologs. Curr Protoc Cell Biol 64: 11.20.1-13, 2014

17. Zhou ZW, Li YX, He ZX, Pan ST, Yang Y, Zhang X, Chow K, Yang T, Qiu JX, Zhou Q, et al: Induction of apoptosis and autophagy via sirtuin 1- and PI3K/Akt/mTOR-mediated pathways by plumbagin in human prostate cancer cells. Drug Des Devel Ther 9: 1511-1554, 2015.

18. Komatsu M, Waguri S, Koike M, Sou YS, Ueno T, Hara T, Mizushima N, Iwata J, Ezaki J, Murata S, et al: Homeostatic levels of p62 control cytoplasmic inclusion body formation in autophagy-deficient mice. Cell 131: 1149-1163, 2007.

19. Inoue D, Suzuki T, Mitsuishi Y, Miki Y, Suzuki S, Sugawara S, Watanabe M, Sakurada A, Endo C, Uruno A, et al: Accumulation of p62/SQSTM1 is associated with poor prognosis in patients with lung adenocarcinoma. Cancer Sci 103: 760-766, 2012.

20. Duan ZL, Peng ZL and Wang ZH: Expression and involved signal transduction pathway of autophagy gene Beclin 1 in epithelialovarian cancer. Sichuan Da Xue Xue Bao Yi Xue Ban 38: 239-242, 2007 (In Chinese).

21. Li Z, Yang B, Guo Y, Zheng QC, Peng Y, Ke WB, Zhang L and Xiong J: Starvation-induced autophage promotes invasion of hepatocellular carcinoma cells. Acta Med Univ Sci Technol Huangzhong 41: 513-517, 2012.

22. Ferrari V and Cutler DJ: Uptake of chloroquine by human erythrocytes. Biochem Pharmacol 39: 753-762, 1990.

23. Hao G, Sun TS and Li SG: Advances in detection of autophagy in mammals. Chin J Clinicians 6: 1531-1533, 2012.

24. Kovács AL, Molnár K and Seglen PO: Inhibition of autophagic sequestration and endogenous protein degradation in isolated rat hepatocytes by methylated adenosine derivatives. FEBS Lett 134: 194-196, 1981.

25. Chen S, Zhou L, Zhang Y, Leng Y, Pei XY, Lin H, Jones R, Orlowski RZ, Dai Y and Grant S: Targeting SQSTM1/p62 induces cargo loading failure and converts autophagy to apoptosis via NBK/Bik. Mol Cell Biol 34: 3435-3449, 2014. 